\title{
Concept Legal Culture of the Volkgeist-Based Customary Land Rights Conflict Resolution of the Dayak Tomun Community in Central Kalimantan Indonesia
}

\author{
Achmadi $^{1}$, Khudzaifah Dimyati ${ }^{2}$, Absori ${ }^{2}$, Sinung Mufti Hangabei ${ }^{3} \&$ Kaji Kelana Usop ${ }^{4}$ \\ ${ }^{1}$ Universitas Muhammadiyah Palangkaraya, Palangka Raya, Indonesia \\ ${ }^{2}$ Universitas Muhammadiyah Surakarta, Surakarta, Indonesia \\ ${ }^{3}$ Faculty of Law, Universitas Muhammadiyah Bengkulu, Bengkulu, Indonesia \\ ${ }^{4}$ Lembaga Musyawarah Masyarakat Dayak Daerah Kalimantan Tengah, Palangka Raya, Indonesia \\ Correspondence: Achmadi, Universitas Muhammadiyah Palangkaraya, RTA Milono KM. 1,5 Langkai \\ Kecamatan Pahandut, Kota Palangka Raya, Kalimantan Tengah, Indonesia. E-mail: achmadiump@gmail.com
}

Received: December 21, 2019

doi:10.5539/ass.v16n1p115
Accepted: December 29, 2019 Online Published: December 31, 2019

URL: https://doi.org/10.5539/ass.v16n1p115

\begin{abstract}
The doctrine of the rule of law provides an opportunity for business actors to exploit the natural resources of the customary forest ecosystem or land of the Dayak Tomun indigenous peoples in Central Kalimantan. The clash between das sollen (supposedly) and das sein (reality) shows how the law is always the instrument of power by the authorities. This study aims to explore the concept of legal culture in resolving volkgeist-based Dayak Tomun customary land rights conflicts sourced from the human nature, which is always interpreted as a correlation between ratio (mindset), behavior, value and rule of law implemented over generations in people's lives. This study uses a mixed research method consisting of normative, empirical, and legal anthropological approaches. The constructive offer of the concept of legal culture has a way of life in the form of norms of rules in terms of customary land rights conflict resolution originating from beliefs, ideas, and thoughts. The concept of legal culture in Halang Lintang is to preserve the legal inheritance, which is used as a cultural foundation and local wisdom to have a legal system, legal process, and the substance of implementing the law as a social control.
\end{abstract}

Keywords: Legal Culture, Dayak Tomun, Local Wisdom

\section{Introduction}

The general conditions of agrarian problems in Indonesia are increasingly complex. The phenomenon of a reality related to land tenure on the indigenous land of local communities is of concern condition for the Dayak Tomun indigenous peoples in Lamandau Regency. At first, the Dayak Indigenous peoples in Central Kalimantan fully believed, waited and accepted all development programs designed from the "Above". However, after living, feeling, understanding and witnessing the reality in the life of the village and inland communities, some principles of ownership of customary land rights apparently have been harmed.

Indonesia is the third largest country with the largest tropical forests in the world and ranks first in the Asia Pacific. The total area of Indonesia's tropical forests is estimated at about 1,148,400 square kilometers, which has large biological natural resources, ranging from mines, flora and fauna. Specifically, from its forests, Indonesia's tropical forests have 400 dipterocarp species, which are the most valuable commercial wood species in Southeast Asia (Jawa Pos Group Multimedia, 2017).

Looking at the history of the formation of law in Indonesia, it is highly influenced by the Dutch legal system. The Netherlands, which had colonized Indonesia for a long time, had inherited positive Dutch law originating from continental Europe and had been colonized by France with a Continental European legal system. Formally and substantially, Indonesia automatically recognizes the positive legal heritage of the Netherlands.

In order to provide legal certainty guarantees, legal positivism rests the philosophy of speculative work (Llyod, 1973) and identifies the law with statutory regulations. Only by identifying the law with statutory regulations will the legal certainty be achieved because people know exactly what they can and cannot do. The law is obeyed not because the value of justice is upheld, but because it has been established by legitimate authorities. 
Legal arrangements that limit and channel various powers and interests in society will now be confronted with the strengths and interests in the community itself. On the other side, the law has an interest obtained through the legislation. Therefore, the regulation must understand the intricacies of the problems it regulates. Also, the law must be aware that factors and powers outside the law that will exert a heavy burden on it and its work processes (Rahardjo, 1980).

In Article 18B paragraph (2) of the 1945 Constitution of the Republic of Indonesia states that the State recognizes and respects traditional communities along with their traditional customary rights as long as these remain in existence and are in accordance with the societal development and the principles of the Unitary State of the Republic of Indonesia, and shall be regulated by law. The existence of indigenous peoples in the forest area will be related to the utilization of forest products. However, the lives of indigenous and tribal peoples are now seriously threatened. The article 18B (2) of the 1945 Constitution uses the doctrinal phrase which states "as long as these remain in existence and are in accordance with the societal development and the principles of the Unitary State of the Republic of Indonesia, and shall be regulated by law". This doctrine provides an opportunity for the threat of big business actors to exploit the natural resources of the customary forest ecosystem or land of indigenous peoples in Indonesia in general and in Central Kalimantan in particular.

Furthermore, Article 28H (4) of the 1945 Constitution says, "Each person has the right to own private property and such ownership shall not be appropriated arbitrarily by whomsoever". Article 28H (4) contains doctrinal phrases that are closely related to human rights. Then, the article 33 paragraph (3) of the 1945 Constitution as the constitutional basis of the economy and social welfare (populist economy) of natural resources reads that earth and water and natural resources contained therein are controlled by the state and used for the greatest prosperity of the people.

The Basic Agrarian Law No. 5 of 1960 states that agrarian law is referred to as customary law described in Article 5, "The Agrarian law which applies to the earth, water and air space is customary Law as far as it is not in conflict with the national and state's interests based on the unity of the nation, with Indonesian socialism as well as with the regulations stipulated in this act and with other laws and regulations, all with due regard to the elements based on the elements based on the purity values of customary law", The formulation of Article 5 of the Basic Agrarian Law Number 5 of 1960 leads to multi-interpretations that are full of political interests. In this connection, it will be difficult to determine whether the existence of a particular indigenous community meets these requirements or not without knowing the community in question. In addition, what is meant by national and state interests and who actually can determine national and state interests are ambiguous.

The doctrinal phrase used as a philosophical and juridical foundation in the management of Indonesia's natural resources can also mean that all natural resources contained in the earth prioritize the greatest prosperity of the people. In fact, there are still other priorities other than just achieving prosperity, namely the principles of justice and prosperity. The clash between das sollen (supposedly) and das sein (reality) shows how the law is always a paradox of the instrument of power by the authorities (capitalism-based corporate system).

According to Biel. L in his journal citing Onorina Botezat's opinion, this is a case of the legal system, which is a distinguishing factor between national cultures. The legal system has its own history, organizing principles, patterns of reasoning and has been designed to answer the needs of a nation. This will definitely lead to the peculiarities of the concept of law among national systems (Biel, 2008; Botezat, 2012).

One example of the problems that occur in the customary land area of the Bayat Village community, Belantikan Raya District, Lamandau Regency is in 2006, the Regent of Lamandau issued a Regent's Decision Number: Decree. Number 525.26/01/VI/2006 which gave permission to PT First Lamandau Timber International to open up 3000 ha of oil palm plantations to enter the customary land of the local community. This is the human rights violations committed by investors. The decree issued by the Regent of Lamandau was only for personal interests by seizing indigenous peoples' rights in Bayat Village, Belantikan Raya District for the expansion of oil palm plantations.

The community rejected the existence of the large private company (PBS), namely PT First Lamandau Timber International, because of the document manipulation including AMDAL/EIA (Environmental Impact Assessment), the statement of community support, release of land documents to obtain permits to the release of forest areas. The oil palm company also did not provide compensation for the planting grown on the customary or private land (Posko Pengaduan Kejahatan Lingkungan Dan Sumber Daya Alam Tahun 2012, Lembaga Musyawarah Masyarakat Dayak Daerah Kalimantan Tengah). The following figure can describe some of the points of territory that have been mapped by the Dayak Tomun indigenous peoples as their customary areas therein: 


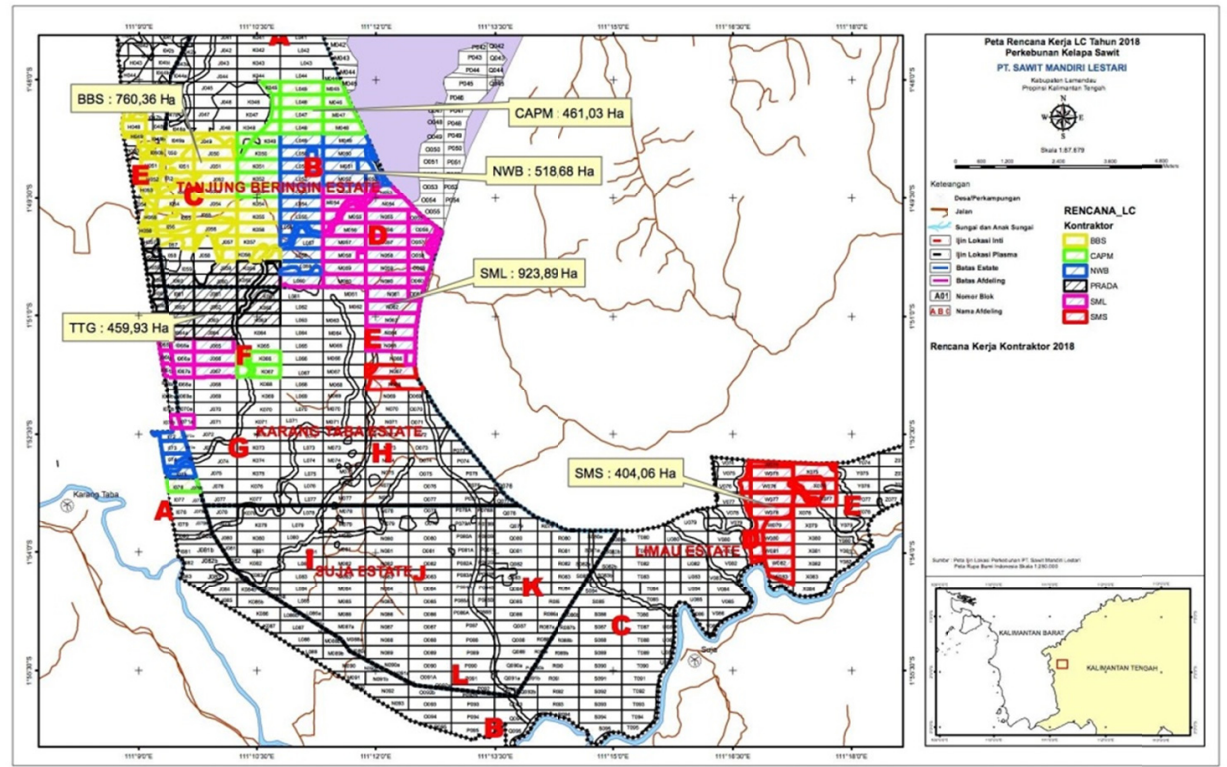

Figure 1. Map of the Customary Area of the Bayat Village Community, Belantikan Raya District

Source: Dayak Tomun community figure in Belantikan Raya District

Batang Kawa District, Lamandau Regency, where the indigenous peoples are in conflict with the PT SML (Sawit Mandiri Lestari) caused by the issuance of the permit of plantation concession right on the local community's customary forest with a plantation area of around 5,000 hectares. Until February 2018, PT SML (Sawit Mandiri Lestari) had expanded its forests by cutting down trees and planting oil palm directly. The area of plantations has reached 1,242 hectares. The picture of customary areas that have been expanded to oil palm plantations can be seen below:

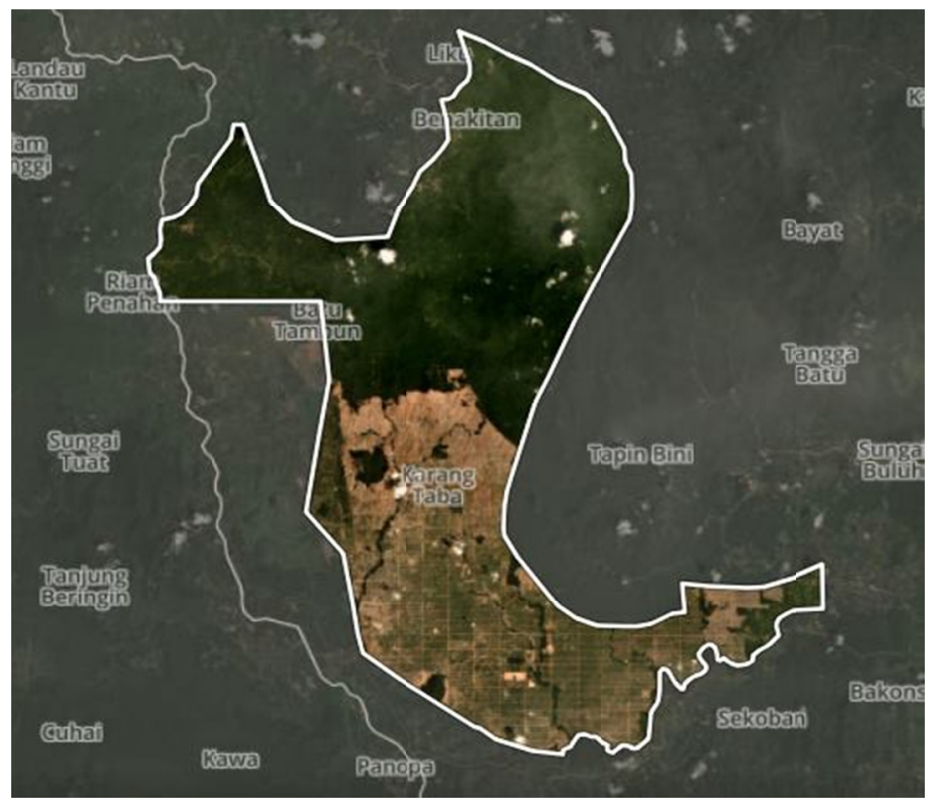

Figure 2. Map of the Damaged Customary Area of Kinipan Village Community, Batang Kawa District Due to Oil Palm Plantation Expansion

Source: Save Kinipan Community Facebook Fan Page

The large number of the oil palm plantation companies that have production factories in Lamandau Regency is factually threatening the existence of the local indigenous peoples' land. Based on data obtained from the Indonesian Palm Oil Association (GAPKI), there are 8 (eight) plantation companies producing crude palm oil (CPO) in Lamandau Regency as shown in the following table: 
Table 1. Data of large plantation companies in Lamandau Regency

\begin{tabular}{lcccc}
\hline NO & Name of Plantation Companies & District & Installed Capacity (Ton/TBS/Hour) & Operational Year \\
\hline & & OPERATIONAL CPO Production & & 2001 \\
1 & PT. Gemeraksa Mekarsari & Bulik & 60 & 2011 \\
2 & PT. Nirmala Agro Lestari & Bulik & 45 & 2012 \\
3 & PT. First Lamandau Timber International & Belantikan Raya & 45 & 2013 \\
4 & PT. Dharma Satya Nusantara & Lamandau & 60 & 2013 \\
5 & PT. Tanjung Sawit Abadi & Mentobi Raya & 60 & 2015 \\
6 & PT. Sawit Multi Utama & Pedongatan & 60 & 2016 \\
7 & PT. Satria Hupasarana & Mentobi Raya & 60 & 2016 \\
8 & PT. Sumber Mahardika Graha & Bulik & 60 & \\
\hline
\end{tabular}

Source: Indonesian Palm Oil Association (GAPKI)

The conflict between norms, values, and behaviors that exist in the community from the chronological problem above is caused by regulations that specifically regulate forests and plantations that conflict with values that exist in indigenous peoples' lives. However, in fact, Law Number 19 of 2004, the amendment to Law Number 41 of 1999 concerning Forestry and Law Number 39 of 2014 concerning Plantations do not fully side indigenous peoples. It can be seen from its implementation, the Law has displaced and expelled the indigenous peoples unit from the customary land area where they live, and which cannot be separated from their lives.

In people's lives, the law is found, not made. Legal growth is organic and is an unconscious process. Therefore, in the legal system, the legislation is less important than customs. Savigny rejects the view of natural law and he believes in the universal law (Pospisil, 1971) that is not bound to the state and its era whose existence is purely derived from thought. He views the legal system depends on its function, specifically related to the culture of society and its history.

Under the term volkgeist (Lloyd, 1973), Savigny constructed his theory of law based on the noble values of people's souls. According to Savigny, there is an organic relationship between law and the nature or character of a nation. The law is only a reflection of volkgeist. Therefore, the 'customary law', which grows and develops in the volkgeist womb, must be seen as the true law of life, which is not made. It must be found in the community and legislation is only important as long as it can abstract values in people's souls which are declarative to their true law. For the Dayak Tomun community, values in culture reflect a set of ideas, thoughts, and norms as the fundamental nature for guidelines for social behaviors (Soewarno, 2018).

Capitalization and the threat of forest conversion by oil palm plantations are a very serious problem faced by indigenous peoples. Values that are violated in the agrarian law source relating to land control, ownership, and redistribution by plantation companies cause problems of inequality of justice, social inequality, and not creating prosperity in the community.

Since the era of colonialism to date, there have been many imbalances between the structures of agrarian relations, both with indigenous peoples and with large plantation companies, in Indonesia. Prolonged social conflicts often occur as a result of the seizure of community land. CF Barber explains that at the same time, the literature on globalization often shows that law moves easily from one country to another and crosses national boundaries. The law is seen as a 'follower camp' of transnational economic and financial development (Cf. Barber, 1991; Cotterrell, 2006).

One of the causes for the exploitation of the environment is the market and corporation. The flow of globalization which results in creative human ideas for technology development and production of merchandise began to become the mainstream in the Asia-Pacific region. One of the main agents is a multinational company that started aggressively and massively launched its economic activities across borders since the 1970s. There are two main characteristics to identify multinational companies, namely expansive and exploitative. Both characteristics are indicated to ignore the impact caused by their activities. Consequently, several environmental issues emerge, such as soil pollution, water pollution, air pollution, and forest destruction. Even further, these environmental problems will threaten the lives of future generations of humans. The regions that become the target for economic expansion and exploitation are developing countries because they still have green and vast areas with abundant natural resources in the Asia-Pacific plains.

Based on the above description, there is an imbalance in translating the meaning, especially about the values, perceptions, attitudes to accept or not to accept a specific law, to the problems of the legal culture of the local 
community. Legal culture, as the most fundamental problem, has a strategic position in determining the choice of behavior to accept the law or actually reject it. In other words, whether a legal product is really obeyed or accepted and used by the community is determined by the legal culture (Sutrisno, 2008).

The significance of this study is to provide the rule of law that that gives more objective justice, not only a political product of the interests of business actors or investors on a global scale. Thus, the legal expectations aspired to by society in the future can prioritize the reflection of hereditary legal culture which is interpreted as a correlation between the ratio (mindset), behaviors, values and rules of law. The main issue to be discussed in this study is related to the concept of legal culture in the volkgeist-based customary land rights conflict resolution as a new proposal for the formulation of legal rules that are just and reflect the legal culture, values, ratios, and behavior.

\section{Method}

This study uses a mixed research method which focuses on the concept of legal culture of the community in resolving conflicts over customary land rights based on human nature which is always interpreted as a correlation between the ratio (mindset), behavior, values and rules of law, which is commonly practice from generation to generation in the lives of indigenous peoples. By using the normative legal paradigm, it studies the law as a normative rule. Then, through an empirical research, the facts of events that are considered relevant to the focus of the study of are directly observed to explain and develop facts in accordance with the prevailing law in the form of sources of human character or patterned behavior in the context of legal culture. In addition, this study is equipped with an anthropological approach to the law to explore symbols, meanings, and hidden things that are believed to exist and seen as law.

\section{Result}

The problem with the community's inability in interpreting the nature of the resolution of conflicts over customary land rights is now still an unresolved polemic. This enables investors to take advantage of these concessions to occupy and take over the customary land that belongs to the community with the legal powers imposed in this country.

National ideals to unite Indonesia as a political and governmental entity tend to ignore the plural and local laws of the people to be replaced with national laws that are unified and codified (Badrulzaman, 1997). This is as stated by Claudiu D. Butculescu (2012) that most doctrines of the theory of law agree that law must be considered to have two sides, namely the static side, an intangible general ideal with the erosion of time, and the dynamic side, a constant adaptation to the demands of society.

The direction of the view above emphasizes the law in terms of the basis for defending the order of market interests. The law is not a tool for creating rules for groups or personal interests of the authorities. The law practice can actually have a transformative effect, one of which is in a system of local community rights.

Since a long time ago until now, the Dayak Tomun people have been familiar with the concept of a legal culture of land rights, called halang lintang (traditional stake), which is as a community preparation for gardening or farming. It can also be interpreted as a form of resistance to maintain the integrity of customary land which is threatened by the land conversion in with inappropriate ways. Halang lintang is adopted from a Central Kalimantan Dayak heritage from the Kaharingan belief, commonly referred to as Hinting.

Before clearing land, for both agriculture and farming, the Dayaks make a purpose mark, so other people would not seize or grab and cultivate the field that has given markers (traditional symbols in the form of tarinting or hinting) or give a stake to the wood from every corner of the pioneered area of vacant land to be cultivated (Usop, 2015).

According to Wendi Soewarno (2018), a local traditional leader, the term halang lintang has cultural values that can be formulated from the context of the local community's customary law including:

1. Ethical values to teach people to uphold and live a civilized life.

2. Moral values to teach humans to maintain attitudes, behavior, and speech in everyday social life.

3. Cultural values originating from the local community to teach indigenous people to respect ancestral heritage and traditional rituals over generations in relation to maintaining relations between humans and nature such as respecting, protecting, and caring for the universe, which has implications in a religious view that land is part of the universe created by God for the common benefit of His creatures.

The Dayak Tomun community has a way of life that is the norm derived from their belief, which has been born from the customs (traditions) that are of existence in the local community, traditions and beliefs that apply and 
exist in the Dayak Tomun community to the present day. In this study, the authors see the anthropological adage included in the legal anthropology section which states that there are no indigenous peoples who do not have a law. This is based on the holistic approach used and the stance that law is part of culture. Cultural phenomena are not merely normative but are symbolic phenomena that give birth to laws for the supporting societies of that culture.

By including the legal culture component, the Dayak Tomun community see the law more realistically. The law is seen as a reflection of the cultural life of the indigenous people which has positive values to know whether the law is used or not in the community life, including errors in the use and abuse of the law. Thus, the legal culture will function as a soul that will bring the whole legal mechanism to life. The correlation between values and ways of life for the Dayak Tomun community is a fundamental nature that regulates customary arrangements including customary law norms, traditional norms of custom order, and norms of belief, in this case with the Kaharingan belief approach.

\section{Discussion}

In the context of resistance, there is a shift of meaning of halang lintang after many plantation investors entering the area of Lamandau Regency. For the local indigenous people, halang lintang aims to defend the rights of a person or group of the Dayak Tomun community by making a mark or symbol by stretching a rope from rattan or wooden root. On the rattan rope hung the lenjuang or sawang leaves accompanied by water drops on the front surface of the leaves with white betel to mark that there is a violation of the agreement in terms of ownership and rights to customary land in the area of land marked by halang lintang. On the other hand, the symbol of rattan rope in halang lintang means that there is still a possibility of negotiation (deliberation or agreement) in resolving conflicts over customary land.

This is in accordance with the objective of halang lintang which invokes the spirits of the land and plants deliberately performed to witness the oath of both conflicting parties like in the spirit trial, where those concerned perform the halang lintang ceremony/tradition to reveal the truth of the owner of the land. If someone lies, then one of the conflicting parties will be dead or undergo a disaster done by the spirits (spiritual violence) to the one who deliberately violates, disturbs, dismantles, violates, and takes over the land of not his/her rights (Soewarno, 2018).

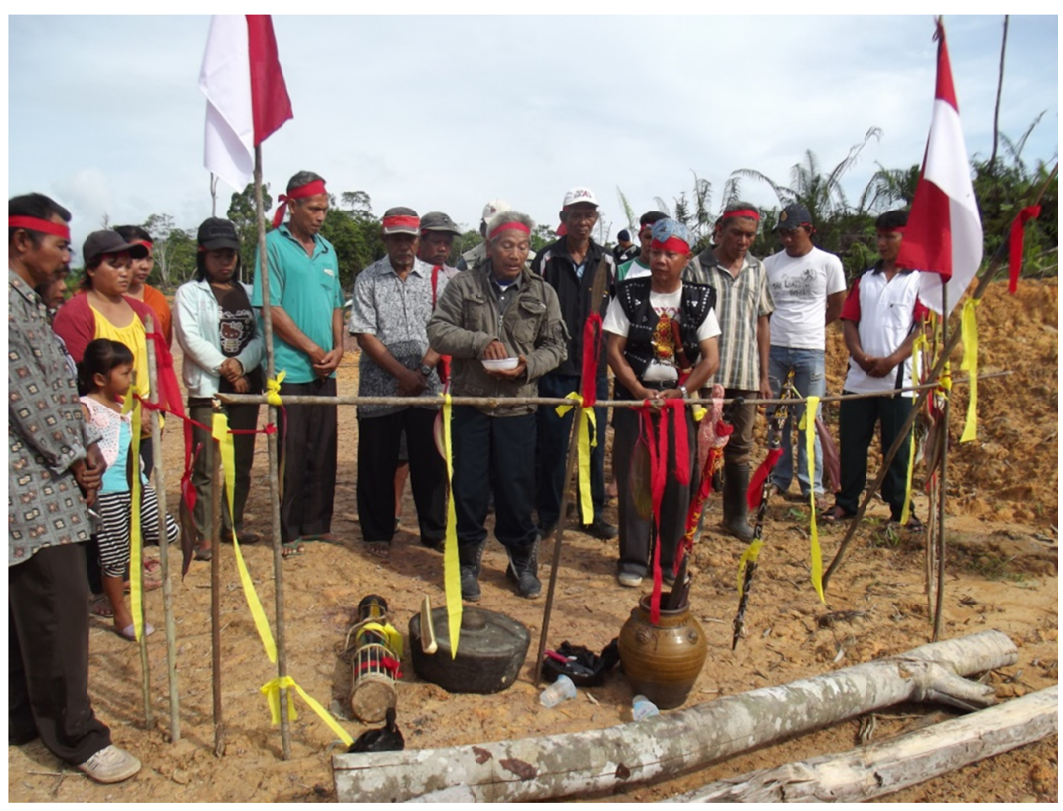

Figure 3. Halang Lintang Ritual of Dayak Tomun indigenous peoples which has the meaning as the legal culture of customary land rights conflict resolution

In context, Halang lintang (traditional stake) is a form of conflict resolution or resistance of the Dayak Tomun indigenous peoples which is interpreted as a form of defending the rights to customary land, which is also formulated in terms of the legal concept of the local community. The concept of the legal culture of the Dayak Tomun community in resolving conflicts over customary land rights in terms of halang lintang is as follows (Soewarno, 2018): 
1. The legal culture of the Dayak Tomun community refers to parts of the culture passed down over generations as a foundation for acting, expressing ideas, thinking, and creating that functions to maintain social order.

2. The legal culture of the Dayak Tomun community is a natural heritage of ancestors who uphold local customs. Determining the legal system, legal process, and substance for the local indigenous community has the aim of living a civilized life (belom behadat).

3. The legal culture of the Dayak Tomun community has local wisdom values based on the beliefs and habits of the local community.

4. The legal culture of the Dayak Tomun community is ideas, thoughts and hopes about implementing the law and maintaining the legal inheritance.

The concept of legal culture in resolving conflicts over customary land rights is inseparable from the philosophy of the customary law of Dayak Tomun "Bosar kocit, kocit hilakng", which means that minimize big problems and eliminate the small ones (Kukung, 2018). The Dayak Tomun indigenous community recognizes the term halang lintang/custom portal (as a symbol of resistance) to assert that the customary land belongs to them. The activities of human and group relations with one another require rules or a set of arrangements as guidelines for behavior (Valerine, 1991). As in primitive law, the law is built on predecessors, where new decisions also rest on old rules of law or norms of customs (Adamson, 1979).

According to Savigny (Arifin, 1990), the law develops along with the history of the people development. It means that the law becomes strong with the strength of the people and disappears if the people lose their nationality. At first, the law developed from customs (traditions) and common beliefs. Then, it developed based on jurisprudence. Thus, every law arises from the similarity of the people's standpoint and does not originate from the will of the legislator.

Carl Von Savigny has a mindset that emphasizes that the power to shape the law lies with the people consisting of a group of individuals and associations, legislators who must come from the people and legal experts by considering a sense of justice in society. For him, the law was born because of the spirit of the people who live in every individual who wants the law to apply. There are two evidences ensuring the existence of certain laws or positive laws. First, there is factual acknowledgment of the community concerned. Second, the law is seen from the actions or behaviors of the people for a long time and has become historical facts (Cahyadi \& Fernando, 2007). The existence of these two evidences is based on the legal function derived from the community's cultural thinking.

In this context, the term halang lintang (traditional stake) for the concept of the legal culture of the Dayak Tomun people originates from the source of ideas, habits, and strength of the community as a form of preparation for gardening or farming and a form of resistance if the customary land is under threat. From this opinion, the legal culture of the local community has several elements that shape it, namely: 1) Customs, 2) Enforcement of legal functionaries (customary council, customary head, and traditional mantir (traditional district leader), 3) Customary sanctions, 4) Unwritten, and 5) Containing elements of belief.

In short, the process of establishing a legal culture can be described in the following scheme:

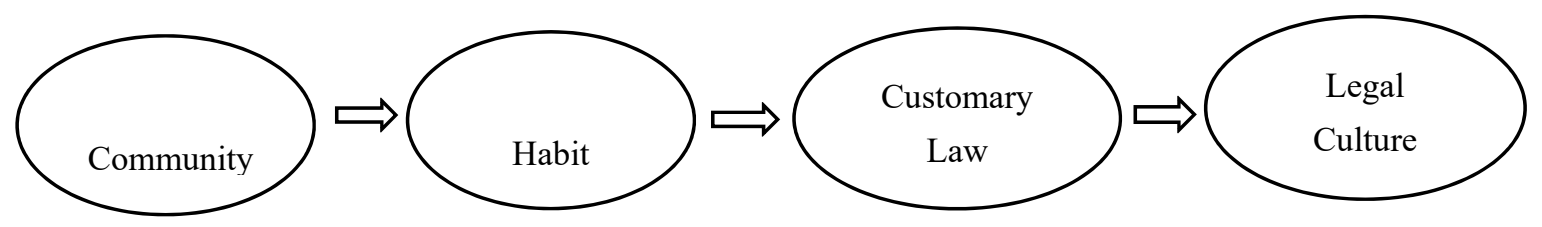

Chart 1. Formation of legal culture

God always creates humans with the nature of the mind in behavior. Humans always uses ratios in their life as a process of reasoning about what is right and wrong. Human rationality creates the behavior that continues to grow into habits that are believed to be the social source of society. The social pattern that has been formed from this habit has been used as a legal source for the community as a way of life, social control, and the application of sanctions that are often referred to as customary law. Customary law is often related to the cultural aspects that form the framework of regulations that are attached to the interests of the community. The context of the legal culture as the main character concerns legal issues and plays an important role as social control in one legal system with another.

The simple concept of legal culture in community land rights conflict resolution based on local wisdom gives a 
philosophical meaning to the nature of human beings in protecting the nature from destruction. As a source of life, indigenous peoples believe that there is a strong relationship between the creator and the universe to be preserved by humans. However, if not preserved or cared for by the local indigenous people, it will cause a catastrophe or disaster.

Further, the researcher portrayed the reality of the field regarding the resolution of conflicts over customary land rights which contain the principles of social, economic, cultural, and religious functions as follows:

1. The principle of social functions, Dayak Tomun peoples position their customary land as an adhesive of social relations. It is forbidden to use the customary land as a tool to exploit the nature and its surroundings or as an object of dispute that leads to social conflicts.

2. The principle of economic functions, Dayak Tomun peoples position their land as a place for living. The customary land serves as the livelihood of the local community, starting from the hunting ground, farming place and livestock breeding ground. It is their duty to keep and preserve the nature.

3. The principle of cultural functions, Dayak Tomun peoples position their land as an ancestral heritage which they believe over generations as a gift from God and which provides a livelihood, so it is closely related to maintaining the relationship between humans and the land.

4. The principle of religious functions, Dayak Tomun peoples still believe in the interference of spiritual power (spirits as the guardians of the nature). This tradition/ceremony has been carried out continuously every year. The essence of the tradition can also strengthen relationships among local communities, so they are always aware of and always protect the surrounding natural ecosystem.

In general, the indigenous community is convinced and believe that the forest has a guardian. Therefore, it is considered a sacred place to be cared for and preserved. Indigenous peoples believe that if the forest ecosystem is destroyed or disturbed, the forest guardians will react and respond to it. This local wisdom by making the forest as a sacred place is very meaningful for the preservation of the forest (Sudun, 2018).

The integration of the legal culture of the Dayak Tomun community in resolving conflicts over customary land rights can be made as a new offer for the legal system in Indonesia. The construction of a legal culture with the local wisdom approach of the Dayak Tomun community is believed to be able to revive the mechanism of the whole legal system. The local wisdom approach comes from habits that are of positive value and are upheld by the local community. In the context of the local wisdom values of conflict resolution products on customary land rights which are obtained from the term halang lintang in the form of ethical values, moral values, and cultural values are also contained in the Pancasila paradigm as the basis of the state which forms the basis of the life of the nation and state of Indonesia.

Therefore, the effect of globalization can crystallize the touch of simple local cultures. Cultural polarization in social spaces reflects the people's mental ground that is very important to maintain the existence of law for local communities. For the adherents of ahistoricism, the manifestation of the nature is very important and systematic, in which local people can recognize, discover, and understand the values of true law in the life of the nation's owner. This argument is based on the precision of social order in the lives of local people that are rational, cultural, and philosophical.

It is not easy to face of legal pluralism today. A justly legal system can integrate the culture as a social heritage, accommodate customary land rights based on local wisdom, culminate codification and unify legal pluralism that is in harmony with the people's soul. In order that this system to be the national law and applicable to all citizens, it must go through a long and thorough process that pays attention to the elements that are closely related to a sense of harmony with the created law and a sense of justice for all elements of society.

\section{Conclusion}

The pattern of legal culture concept involves the Dayak Tomun community, which is based on their ideas, habits, and strength of the local wisdom as a form of way of life in the form of norms in the resolution of conflicts over customary land rights. Norms of rules are very simple and contain ethical, moral, and cultural values. Legal culture as a form of local wisdom is the main character of law and plays an important role as a social control in the legal system. The concept of legal culture is used as a cultural foundation, local wisdom, and is natural in having a legal system, legal process, and the substance of implementing the law and preserving legal inheritance as a social control. Values, norms, and legal culture concepts based on local wisdom need to be accommodated in codification and unification into the national law. 


\section{References}

Badrulzaman, M. D. (1997). Mencari Sistem Hukum benda Nasional. Alumni, Bandung.

Biel, Ł. (2008). Legal Terminology in Translation Practice: Diction-aries, Googling or Discussion Forums? SKASE Journal of Translation and Interpretation [online], 3(1), 23. Retrieved from http://www.skase.sk/Volumes/JTI03/pdf_doc/BielLucja.pdf

Botezat, O. (2012). The Complexity of Legal Translation: Social and Cultural Bounds Aspects. Contemporary Readings in Law and Social Justice, 4(1). Retrieved from https://www.questia.com/library/journal/1P3-2772533731/the-complexity-of-legal-translation-social-and-cu ltural

Butculescu, C. D. (2012). New Developments Regarding Legal Cultures in Europe. Exploring Legal Conflicts in the Multicultural Society. Contemporary Readings in Law and Social Justice, 4(1). Retrieved from https://www.questia.com/library/journal/1P3-2772533351/new-developments-regarding-legal-cultures-in-eu rope

Cahyadi, A., Manullang, E., \& Fernando, M. (2007). Pengantar ke Filsafat Hukum. Jakarta, Prenada Media Group.

Cotterrell, R. (2006). Culture, Comparison, Community. International Journal of Law in Context, 2(1). https://doi.org/10.1017/S1744552306001017

Friedmann, W. (1990). Teori dan Filsafat Hukum (Vol. I2). Translated by Muhammad Arifin and Legal Theory, CV Rajawali, Jakarta.

Hoebel, E. A. (1979). The Law of Primitive Man. New York: Harvard University Press.

Jawa Pos Group Multimedia. (2017). Retrieved March 16, 2017, from http://www.mongabay.co.id/2018/06/18/begini-nasib-hutan-laman-kinipan-kala-investasi-sawit-datang/

Kukung, M. (2018). Direct Interview with Dayak Tomun Traditional Figure. Lamandau. Central Kalimantan.

Llyod, D. (1973). The Idea of Law. Harmondsworth, Penguin Books.

LMMDD-KT. (2012). Lembaga Musyawarah Masyarakat Dayak Daerah Kalimantan Tengah. Laporan Posko Pengaduan Kejahatan Lingkungan Dan Sumber Daya Alam.

Pospisil, L. (1971). Anthropology of Law: A Comparative Theory. Harper \& Row, Publishers, New York. NY

Rahardjo, S. (1980). Hukum dan Masyarakat. Bandung, Angkasa.

Soewarno, W. (2018). Direct Interview with Dayak Tomun Traditional Figure. Lamandau. Central Kalimantan.

Sudun, A. (2018). Direct interview with the caretaker of "Laman Karang Bosi" Belantikan Raya District. Lamandau Central Kalimantan.

Sutrisno, E. (2008). Budaya Hukum Masyarakat Dalam Melindungi Pencemaran Lingkungan. Swagati Press, Cirebon.

The 1945 Constitution of the Republic of Indonesia.

Usop, L. S. (2015). Maniring Hinting Sebagai Gerakan Kontra Hegemoni Masyarakat Dayak Dalam Pembertahanan Hak-Hak Atas Tanah di Kabupaten Kotawaringin Timur (Dissertation of Postgraduate Program of Universitas Udayana Denpasar).

Valerine, J. K. L., \& Kriekhoff. (1991). Kedudukan Tanah Dati sebagai Tanah Adat di Maluku Tengah; Suatu Kajian dengan Memanfaatkan Pendekatan Antropologi (Dissertation of Postgraduate Doctoral Program of Universitas Indonesia).

\section{Copyrights}

Copyright for this article is retained by the author(s), with first publication rights granted to the journal.

This is an open-access article distributed under the terms and conditions of the Creative Commons Attribution license (http://creativecommons.org/licenses/by/4.0/) 